\title{
ORIGINAL ARTICLE \\ PATTERN OF RED CELL COUNT AND RED CELL DISTRIBUTION WIDTH (RDW \%) IN BETA THALASSAEMIA TRAIT IN ADULTS
}

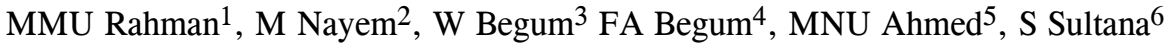 \\ ${ }^{1}$ Dept of Biochemistry, Dhaka National Medical College, Dhaka; ${ }^{2}$ Dept of Physiology, Dhaka National \\ Medical College, Dhaka; ${ }^{3}$ Dept of Dermatology \& Venereology, Dhaka National Medical College \\ Dhaka; ${ }^{4}$ Dept of Biochemistry, Tairunessa Memorial Medical College, Dhaka; ${ }^{5}$ Dept of Physiology \\ Army Medical College, Comilla; ${ }^{6}$ Dept of Biochemistry, Marks Medical College, Dhaka
}

\section{ABSTRACT}

\begin{abstract}
Microcytic hypochromic anemia is one of the commonest hematological abnormalities in Bangladeshi population. Iron deficiency anemia and beta thalassemia traits are the most frequent causes of microcytic hypochromic anemia which are sometimes difficult to differentiate clinically and by routine laboratory examinations due to similar blood picture. To differentiate between patients of beta thalassemia trait and iron deficiency anemia, physicians need a group of investigations including peripheral blood film, estimation of $\mathrm{HbA}_{2}$, serum ferritin, serum iron, total iron binding capacity and transferrin saturation. But these tests are relatively expensive, time consuming and need sophisticated techniques. The aim of this study was to evaluate the pattern of red cell count and RDW-CV (\%) in beta thalassemia trait in adults and thereby determine the role of these parameters in differentiation between patients of beta thalassemia trait and iron deficiency anaemia. In this study 50 confirmed cases of beta thalassemia trait aged 18 to 60 years, both male and female were included as cases and 50 age- and sex-matched iron deficiency subjects were included as control. RBC count and RDW-CV (\%) were measured by an electronic cell counter device. The present study revealed that $\mathrm{RBC}$ count was higher in patients with beta thalassemia trait than that in iron deficiency anemia and RDW-CV(\%) was significantly higher in patients with iron deficiency anemia than that in beta thalassemia trait.
\end{abstract}

Key Words: Beta Thalassemia Trait, Iron deficiency anemia, Red cell distribution width

\section{Introduction}

Microcytic hypochromic anemia is one of the commonest haematological abnormalities that a clinician come across in Bangladesh. The most common causes of microcytic hypochromic blood pictures are iron deficiency anemia (IDA) and beta thalassemia trait $(\mathrm{BTT})^{1}$. It is sometimes difficult to differentiate them clinically and by routine laboratory examinations due to similar blood picture ${ }^{2,3}$. The degree of microcytosis and hypochromia relates to both the severity and the duration of underlying disorders. These abnormalities may be difficult to detect when the underlying defect is mild, early or fluctuating ${ }^{4}$. But the differentiation between beta thalassemia trait and iron deficiency anemia has important clinical implications 5 .

In last four decades many formulae have been proposed to discreminate between these two

Bangladesh J Med Biochem 2016; 9(1): 31-35 
32 Bangladesh J Med Biochem 2016; 9(1)

common causes of microcytic hypochromic anemia. These formulae are based on $\mathrm{Hb} \%, \mathrm{RBC}$ count, $\mathrm{MCV}$ and $\mathrm{RDW}^{6}$. The accepted protocol for diagnosis of iron deficiency anaemia and beta thalassemia trait in routine haematology laboratories is the performance of complete blood count (CBC), serum iron profile, haemoglobin electrophoresis and $\mathrm{HbA}_{2}$ quantification ${ }^{7}$. However, it has been proposed that the routine electronic red blood cell (RBC) counts and indices derived from modern blood cell analyzers can provide valuable clues as to whether beta thalassemia trait or iron deficiency anemia may be present ${ }^{4}$.

New automated blood cell counter provide an index of red cell volume distribution width (RDW), an important parameter in differentiation between beta thalassemia trait and iron deficiency anemia ${ }^{8}$. The RDW quantitatively measures red cell size variation, computed directly from the RBC histogram and is expressed in SD (fl) and CV (\%), Co-efficient of variation of the volume distribution ${ }^{9}$. McClure et al showed that RDW is the first index of the routine blood cell to become abnormal during the development of iron deficiency ${ }^{10}$. RDW is a measure of anisocytosis, increase in iron deficiency anaemia and it is normal or mildly increased in beta thalassemia trait. RDW has been reported to be a good discrimination index to differentiate beta thalassemia trait and iron deficiency anemic patients 9 .

Patients with IDA have the most severe anemia and most severe degree of anisocytosis, as they have the lowest mean $\mathrm{Hb}(8.7 \mathrm{~g} / \mathrm{dL})$ and highest mean RDW (21.7\%). In contrast, the BTT group has the highest mean $\mathrm{Hb}(10.9 \mathrm{~g} / \mathrm{dL})$ and lowest mean RDW (17.6\%), indicating less severe anemia and less severe anisocytosis ${ }^{11}$. Shalev et $a l .{ }^{7}$ reported that the combination of high $\mathrm{RBC}$ count and normal RDW is characteristic of BTT.

BTT must be differentiated from IDA and other causes of microcytosis. Automated red cell parameters, such as MCV, RBC count, and red
MMU Rahman, M Nayem, W Begum et al

cell distribution width (RDW), have been used to identify patients with a high probability of BTT $^{1}$. These automated red cell parameters are routinely examined and offer a rapid and reliable method for BTT screening. Adequate utilization of these parameters can facilitate identification of the majority of BTT cases at no additional cost to the health care system ${ }^{11}$.

To differentiate between patients of iron deficiency anemia and beta thalassemia trait, physician needs a group of investigations including estimation of $\mathrm{HbA}_{2}$, peripheral blood film, serum ferritin, iron, total iron binding capacity and transferrin saturation ${ }^{12}$. But these are relatively expensive, time consuming and need sophisticated techniques. Red cell count and red cell volume distribution (RDW) curves generated easily by electronic cell counters and can reliably distinguish microcytosis caused by beta thalassemia trait and iron deficiency anemia ${ }^{13}$.

Estimation of $\mathrm{HbA}_{2}$ by hemoglobin electrophoresis is an important tool to diagnosis beta thalassemia trait. Where this facility is unavailable preliminary microscopic examination of hypochromic and microcytic anemic cases and subsequent measurement of the red cell count and RDW may guide to perform hemoglobin electrophoresis. Identifying beta thalassemia trait and counseling them about the genetic implications of marrying another carriers will be the most effective method for preventing beta thalassemia major.

\section{Materials \& Methods}

This cross-sectional study was carried out in the Department of Biochemistry and Department of haematology, Dhaka Medical College in collaboration with Dhaka Shishu Hospital Thalassemia Center (DHTC), Sher-e-Bangla Nagar, Dhaka from July 2009 to June 2010.

Cases were selected as beta thalassemia trait and iron deficiency anemia on the basis of $\mathrm{Hb}$ 
electrophoresis and serum ferritin level. In patients with microcytic hypochromic anemia having normal serum ferritin level and $\mathrm{HbA}_{2}$ level more than $3.5 \%$ were diagnosed as beta thalassemia trait ${ }^{14}$. $\mathrm{HbA}_{2}$ level less than $3.5 \%$ provided with low serum ferritin (less than 12 $\mathrm{ng} / \mathrm{ml}$ ) was considered as patients with iron deficiency anemia ${ }^{15}$. Sample size was 100 , both male and female aged 18 to 60 years were included in this study. Among them 50 were the patients of iron deficiency anemia and 50 were beta thalassemia trait.

$5 \mathrm{ml}$ of venous blood was withdrawn aseptically from antecubital vein and collected into bottles containing EDTA as anticoagulant. Blood samples from all patients were analyzed by automated cell counter, Cell Dyn 3700 (Abbott, USA). This instrument was calibrated daily with normal, high and low controls provided by the manufacturer before running the specimen. RBC count and RDW-CV (\%) were measured by an electronic cell counter device. Data were processed and analyzed by using computer software SPSS (Statistical Package for Social Sciences), Version-16. Quantitative data were expressed as mean \pm SD. Values of the different parameters were compared to see the difference between two groups by using student's t-test. $\mathrm{p}<0.05$ was considered as significant.

\section{Results}

Table: RBC Count $\left(10^{12} / 1\right) \&$ RDW-CV (\%) in study subjects

\begin{tabular}{ccccc}
\hline \multirow{2}{*}{ Parameters } & \multicolumn{2}{c}{ Groups } & & \\
\cline { 2 - 3 } & $\begin{array}{c}\text { BTT } \\
(\text { Mean } \pm \text { SD })\end{array}$ & $\begin{array}{c}\text { IDA } \\
(\text { Mean } \pm \text { SD) }\end{array}$ & & P value \\
\hline $\begin{array}{c}\text { RBC Count } \\
\left(10^{12} / 1\right)\end{array}$ & $5.8 \pm 0.12$ & $4.3 \pm 0.23$ & 29.34 & 0.0001 \\
RDW- & $14.26 \pm 0.46$ & $18.52 \pm 2.54$ & 8.51 & 0.0001 \\
CV $(\%)$ & & & & \\
\hline
\end{tabular}

Table shows that mean RBC count was (5.8 $\pm 0.12) \times 10^{12} / 1$ in BTT and it was $(4.3 \pm$ $0.23) \times 10^{12} / 1$ in IDA. A statistically significant mean difference was found, indicating BTT had higher RBC count than IDA. The mean level of RDW-CV (\%) was $(14.26 \pm 0.46)$ in BTT and the mean level of RDW-CV(\%) was (18.52 \pm $2.54)$ in IDA. A statistically significant mean difference was found, indicating IDA had higher RDW-CV(\%) than BTT.

\section{Discussion}

Microcytic hypocromic blood picture is one of the commonest findings encountered during peripheral blood film examination. A vast majority of such cases have iron deficiency and $3 \%$ of total population that is about 3.6 million people of our country has beta thalassemia trait. Differentiation between patients of IDA and BTT becomes a problem due to similar microscopic blood picture. It is very important to distinguish between these two entities ${ }^{16}$ for proper management.

The differentiation between BTT and IDA relies on the measurement of serum ferritin, serum iron and $\mathrm{HbA}_{2}$ levels. But these methods are expensive and time consuming ${ }^{17}$. Again morphological appearance of red cells in blood film in IDA and BTT mimics so closely that it becomes sometimes very difficult in differentiating these two conditions ${ }^{18}$. New automated blood cell counters provide red cell count and an index of red cell volume distribution width (RDW) which are important parameters in differentiation between IDA and $\mathrm{BTT}^{8}$.

According to Demir, RBC count and RDW are the most reliable discrimination indices in differentiation between beta thalassemia trait and iron deficiency anemia ${ }^{19}$. In a study by Bessman and Feinstein ${ }^{20}$, the mean number of RBC count was normal in beta thalassemia trait. This result does not agree with the result of the present 
34 Bangladesh J Med Biochem 2016; 9(1)

study. The present study shows that the mean level of RBC count was $(5.8 \pm 0.12) \times 10^{12} / 1$ in BTT and it was $(4.3 \pm 0.23) \times 10^{12} / 1$ in IDA. A statistically significant mean difference was found, indicating BTT had higher RBC count than IDA. The findings of this study regarding RBC count agree with the study of Isaacs, Altman and Valman ${ }^{21}$, they found that beta thalassemia trait had significantly higher numbers of red cells.

RDW is a measure of anisocytosis. It increases in IDA and is normal or mildly increased in BTT. RDW has been reported to be a good discrimination index to differentiate BTT and IDA $^{9}$. The present study shows that the mean level of RDW-CV(\%) was (14.26 \pm 0.46$)$ in BTT and the mean level of RDW-CV(\%) was $(18.52 \pm 2.45)$ in IDA. A statistically significant mean difference was found, indicating IDA had higher RDW-CV(\%) than BTT. This result does not correlates with the results of Ayatun Nesa et $a l .{ }^{22}$, who found the mean RDW to be $16.4 \%$ in BTT and $16.9 \%$ in IDA and the difference was not statistically significant $(p=0.269)$. But the result of the study by Vishwanath et al. ${ }^{23}$ showed that RDW was elevated and was more sensitive in detecting iron deficiency anemia than peripheral smear. In that study, they concluded that RDW is $100 \%$ sensitive in mild degrees of anemia, thus aiding early diagnosis of iron deficiency anemia. McCluer et al. ${ }^{24}$ concluded in their study that RDW was $100 \%$ sensitive and it was useful in early detection of iron deficiency anemia. Patton et al. ${ }^{25}$ showed that an elevated RDW appears to be the earliest haematological manifestation in iron deficiency anemia. All these results are consistent with the results of present study.

From above discussion it may be concluded that subjects of microcytic hypochromic blood picture having high red cell count but normal RDW-CV\% are suggestive of BTT. But subjects of microcytic hypochromic blood picture having
MMU Rahman, M Nayem, W Begum et al

high RDW-CV\% and normal red cell count are suggestive of IDA. In this situation these disorders should be further confirmed by haemoglobin electrophoresis by estimating $\mathrm{HbA}_{2}$ level and serum ferritin level.

The outcome of the study suggests that measurement of red cell count and RDW-CV\% are important tools to guide the physicians to differentiate between beta thalassemia trait and iron deficiency anemia. These tests also help to determine which sample should be tested for thalassemia and which sample for iron deficiency anemia, thereby providing a costeffective diagnostic protocol.

\section{References}

1. Kotwal J, Saxena R, Choudhry VP, Dwivedi SN, Bhargava M. Erythrocyte indices for discriminating thalassemic and nonthalassemic microcytosis in Indians. Natl Med J India 1999; 12: 266-267.

2. Wharton BA. Iron deficiency in children: detection and prevention. Br J Haematol 1999; 106: 270-80.

3. Olivieri NF. The beta-thalassemias. N Engl J Med 1999; 341: 99-109.

4. Firkin F, Chesterman C, Penington D, Rush B. In; de Gruchy's Clinical Haematology in Medical Practice; 1991, 5 $5^{\text {th }}$ ed. Oxford University Press Delhi, pp. 50-51: 156-157

5. Hallberg L. Iron requirements: comments on methods and some crucial concepts in iron nutrition. Biol Trace Elem Res 1992; 35: 25-45.

6. Bain BJ. Haemoglobinopathy Diagnosis; 2001, $1^{\text {st }}$ ed. Blackwell Science Oxford, 77.

7. Shalev O, Yehezkel E, Rachmilewitz EA. Inadequate utilization of routine electronic RBC counts to identify Beta Thalassemia Carriers. Am J Public Health 1988; 78: 1476-77. 
8. Aslan D, Gumruk F, Gurgey A, Altay C. Importance of RDW value in Differential Diagnosis of Hypochrome Anemias. Am $\mathbf{J}$ Hematol 2002; 69: 31-33

9. Novak RW. Red Blood Cell Distribution Width in Pediatric Microcytic Anemias. Am J Hematol 1987; 80: 251-54

10. McCulure S, Custer E, Bessmann JD. Improved detection of early iron deficiency in nonanaemic subjects. JAMA 1985; 253: 1021-23.

11. Parthasarathy Veda. A Search for Beta Thalassemia Trait in India. Turk J Haematol Dec 2012; 29(4): 427-429.

12. Lima CSP, Reis ARC, Gotto HZW, Saad STO, Costa FF. Comparison of red cell distribution width and a red cell discriminant function incorporating volume dispersion for distinguishing iron deficiency from beta thalassemia trait in patients with microcytosis. Sao Paulo Medical Journal 1996; 114: 1265-65.

13. Johnson CS, Tegos C, Beutler E. Thalassemia Minor: Routine Erythrocyte Measurements and Differentiation from Iron Deficiency. Am J Clin Pathol 1983; 80: 31-36.

14. Clarke GM, Higgins TN. Laboratory Investigation of Hemoglobinopathies and Thalasssemias: Review and Update. Clin Chem 2000, 46: 8(B) 1284-1290.

15. Clark SF. Iron Deficiency Anemia. Nutr Clin Pract 2008; 23: 128-141.

16. Selimuzzaman M, Belayet M, Mamm MAA, Mamum M, Khasru AM, et al. Frequency of coincident of iron deficiency and $\beta$ thalassemia trait in Bangladeshi Children. DS (child) HJ 2008; 24: 27-32.

17. Ntaios G, Chatzinikolaou A, Saouli Z, Girtovitis F, Tsapanidou M, Kaiafa G, et al. Discrimination indices as screening tests for $\beta$-thalassemia trait. Ann Hematol 2007; 86: 487-91.
18. Abedin AKMM, Rahman MM, et al. Value of Red Cell Distribution Width Index As A Diagnostic Tool In Iron Deficiency Anemia And Various Congenital Haemoglobin Disorders. Bangladesh J Pathol 2006; 21: 14-18.

19. Demir A, Yarali N, Fisgin T, Duru F, Kara AR. Most reliable indices in differentiation between thalassemia trait and iron deficiency anemia. Pedia Int 2002; 44: 612-6.

20. Bessma JD, Feinstein DI. Quantitative anisocytosis as a discriminant between iron deficiency and thalassemia minor. Blood 1979; 53: 288.

21. Isaacs D, Althman DG and Valman HB. Racial differences in red cell indices. J Clin pathol 1986; 39: 105-109.

22. Nesa A, Tayab MA, Sultana T, Khondoker L et al. RDWI is Better Discriminant than RDW in Differentiation of Iron Deficiency Anemia and Beta Thalassemia Trait. Bangladesh $\mathbf{J}$ Child Health 2009; 33(3): 100-103

23. Vishwanath D et al. Red Cell Distribution Width in the diagnosis of Iron Deficiency Anemia. Ind J Ped 2001; 68(12): 1117-1119.

24. Mc Clure S, Custer Eand Bessman JD. Improved detection of early Iron Deficiency in anemic subjects. J Am Med Assoc 1985; 253(7): 1021-1023

25. Patton WN and Cave RJ. A study of changes in Red cell volume and Hemoglobin concentration during Phlebotomy induced Iron Deficiency and Iron Depletion using the Tenhion Hi. Clin Lab Haematol 1991; 13: 153-161. 